\title{
Comparison of Indoor Air Quality in Eateries Within Zaria Metropolis
}

\author{
Osianemo Andrew Omole*, Ikem Mbamali, Dalhatu Abdulsalam \\ Department of Building, Faculty of Environmental Design, Ahmadu Bello University, Zaria, Nigeria \\ Email address: \\ omoleosianemo@gmail.com (O. A. Omole) \\ ${ }^{*}$ Corresponding author

\section{To cite this article:} \\ Osianemo Andrew Omole, Ikem Mbamali, Dalhatu Abdulsalam. Comparison of Indoor Air Quality in Eateries Within Zaria Metropolis. \\ International Journal of Atmospheric and Oceanic Sciences. Vol. 4, No. 1, 2020, pp. 1-6. doi: 10.11648/j.ijaos.20200401.11
}

Received: September 4, 2019; Accepted: December 23, 2019; Published: January 7, 2020

\begin{abstract}
Good indoor air quality in eateries is essential for ensuring healthy and comfortable workplace environment and enhancing visiting customer comfort and eatery personnel output and productivity. This study assessed the indoor air quality (IAQ) of selected Eateries in Zaria metropolis with a view to identifying the sources of pollutants and verifying their acceptability in relation with existing guidelines. The study relates to the concentration levels of specific indoor air quality indicators; temperature, relative humidity, carbon mono oxide, carbon dioxide, total volatile organic compounds, formaldehyde, particulate matter 2.5 and particulate matter 10. It was carried out by means of field survey, involving measurements and use of a well-structured checklist for relevant data collection on 13 eateries in Zaria metropolis. Two indoor locations (Dinning and Kitchen) were selected per eatery and four air samples collected at each, over a space of 15 minutes during the harmattan season. Findings showed that the highest mean level of Temp $\left(30.9^{\circ} \mathrm{C}\right), \mathrm{RH}(49.2 \%)$, $\mathrm{CO}$ (21 ppm), $\mathrm{CO}_{2}(890 \mathrm{ppm})$, TVOC $\left(0.237 \mathrm{mg} / \mathrm{m}^{3}\right), \mathrm{HCHO}\left(0.170 \mathrm{mg} / \mathrm{m}^{3}\right)$, PM2.5 $\left(60 \mu \mathrm{g} / \mathrm{m}^{3}\right)$ and PM10 $\left(62.9 \mu \mathrm{g} / \mathrm{m}^{3}\right)$ were found in the eateries $F$ and M. Results from the inferential statistics showed significant differences $(p<0.05)$ in dinning and kitchen for $\mathrm{CO}$ and PM2 respectively. Also, significant differences were seen in the four sampling sessions for all pollutants at different Eateries. In addition, Eateries should provide functioning exhaust, ventilation, and air conditioning facilities and air cleaning systems must be maintained and its parts must be inspected and cleaned based on the specifications approved by ASHRAE standard 62 .
\end{abstract}

Keywords: Indoor Air Quality (IAQ), Eateries, Pollutants

\section{Introduction}

In pursuit of energy efficiency, enclosed or tighter houses that are energy-efficient to save cooling and heating costs are been built. However, there should be concerns about the indoor air quality of this enclosed building with adequate ventilation. Clean air is a basic requirement for life and healthy living. The quality of air in homes, offices, eateries, schools, day care centres, public buildings, health care facilities and other private and public buildings where people spend over $80-90 \%$ of their time daily is crucial for healthy living and people's well-being [1]. The National Health and Medical Research Council (NHMRC) defines indoor air as air within a building occupied by people of varying states for a period of at least one hour [2]. Buildings covered by this definition include homes, schools, eateries, public buildings, residential institutions, offices, etc.

Eateries have extensively evolved to become controlled environments with sophisticated ventilating and airconditioning systems. However, little is known about Indoor Air Quality (IAQ) in these modern eateries. In recent years, eateries have not been extensively studied compared to other equally important indoor environments in terms of time spent by the population, such as dwellings, office and schools [3]. Human beings need a regular supply of food and water and an essentially continuous supply of air as they spend a considerable amount of their time breathing air inside an enclosed space in which, various sources of contaminants may deteriorate the air quality. This is an important risk factor for health of the general population. The requirements for air and water are relatively constant as $10-20 \mathrm{~m}^{3}$ and $1-2$ litres per day, 
respectively [4]. According to [5], an average human being requires about $12 \mathrm{~kg}$ of air each day, which is nearly 12 to 15 times greater than the amount of food consumed. Indoor air pollution is currently a major public health concern, given the fact that most people spend $80-90 \%$ of their times at indoor for working, living, etc. and the various pollutants present in indoor environments may be harmful to human health [6].

Studies for assessing the indoor air quality of eateries are required for evaluating the potential health risks, establishing guidelines, and advocating possible control measures for ensuring the healthy workplace environment [7]. Although studies dealing with eateries' air quality are scarce in the literature, few of such studies have been carried out in different parts of the world which indicated a serious indoor air quality problem, particularly in developing countries [8]. The deteriorated air quality in areas surrounding the eateries is an additional challenge, as the exhaust chimneys of eateries' kitchens typically are not equipped with any pollution control devices such as scrubbers, catalysts, or condensers [9]. Many attendants of public places like eateries are subjected to effects like dizziness, wet eyes, drowsiness and general discomfort due to nature of the activities taken place such as cooking, smoking and the tightness of the building [6]. Thus, the risks to health which will lead to the decrease of patronizes and employee productivity through exposure to indoor air pollution [10]. Clearly, the quality of indoor air should be as high as possible. Thus, this study assesses the indoor concentrations of air pollutants at different selected eateries in Zaria and compares the results with air quality standards. The objective was to Determine the acceptability of the indoor air quality of the selected eateries by comparing with IAQ guidelines.

\section{Literature Review}

Indoor Air Quality (IAQ) was firstly investigated in 1970s [11] after the energy crisis and continues until these days because it is a basic determinant of healthy life and people's wellbeing, comfort and productivity [12]. New requirements for buildings, such as insulated windows, caused common air contaminants to become trapped [13]. American Society of Heating, Refrigerating and Air-Conditioning Engineers (ASHRAE) define acceptable Indoor Air Quality (IAQ) as "Air in which there are no known contaminants at harmful concentrations as determined by cognizant authorities and with which a substantial majority $(80 \%$ or more) of the people exposed do not express dissatisfaction." [14]. IAQ problems arise from interactions between the building materials, activities that occur in the building, climate and the building occupants [13]. These problems may arise from inadequate temperature, poor ventilation systems, indoor air contaminants, or from insufficient outdoor air intake [15] In general, the types of pollutants that may affect IAQ are biological, chemical, particles and aerosol pollutants. Biological pollutants include bacteria, fungi, pollen, and animal dander. Chemical pollutants include adhesives, cleaners, solvents, combustion by-products and emissions from floor or wall coverings. Particles and aerosols are solids and liquids suspended in air, from dust, construction, smoking, or combustion [15]. For the purposes of this study, the stressors discussed will include $\mathrm{CO}, \mathrm{CO}_{2}$, TVOC, $\mathrm{HCHO}$, PM2.5, PM10 and the comfort parameters temperature and relative humidity.

\subsection{Indoor Air Pollution}

Air pollution is "the presence in the atmosphere of a foreign substance composition of normal or important change in the proportions of its component, which can be harmful and/or directly or indirectly induce changes on health [16]. According to the World Health Organization [4], polluted air is linked to a variety of health concerns, ranging from short-term irritation to serious diseases or even death. Poor air quality has been shown to exacerbate chronic respiratory diseases, which are diseases of the airway and lungs [4].

The quality of indoor air is influenced both by the quality of outdoor air and by the emission characteristics of indoor sources [17]. The concentration of air pollutant at indoors depends on a number of factors such as: volume of air present in the indoor, rate of release the pollutants into the indoor, rate of elimination of the pollutants from the indoor, rate of air exchange with the outside through ventilation and the concentration of the pollutant outdoors. Nigeria, unlike the developed countries is faced with several environmental, social and economic challenges such as inadequate electric power supply, poor waste disposal system, air pollution, water pollution, noise pollution, unemployment, inadequate of water supply, etc. [18].

\subsection{Sources of Indoor Air Pollutants}

There are many sources of indoor air pollution in an enclosed environment. Some of these pollutants come from sources such as combustion (airborne particles of different sizes and harmful gases), building materials (airborne particles of different sizes and out gassing), and furnishings (out gassing). Combustion pollutant sources include oil, gas, kerosene, coal, wood, and tobacco products. Building materials and furnishings can be very diverse. For example, asbestos insulation, wet carpet, cabinetry, and furniture made of some pressed woods are different examples of building materials and furnishings that release pollutants [19]. Household cleaning and maintenance chemicals and personal care products can add contaminants to the indoor air. These pollutants decrease indoor air quality and can be a health risk to occupants.

\section{i. Biological Pollutant Sources}

Biological pollutants include viruses, bacteria, pet saliva, molds, and dust mites. These pollutants can cause serious health issues. Contaminants like bacteria can trigger allergic reactions such as pneumonitis and asthma. Viruses can cause infectious illness such as influenza. A common source for 
biological pollutants is mold. It grows in the dark and humid areas around the house. Mold can trigger an allergic reaction in some people, including eye or throat irritation, coughing and headaches. Pets are a major source of indoor air pollutants [20]. All of these biological contaminants are a direct risk to user health.

ii. Chemical Pollutant Sources

Sources of chemical pollutants (gases and vapours) include emissions from products used in the building (e.g., office equipment; furniture, wall and floor coverings; pesticides; and cleaning and consumer products), accidental spills of chemicals, products used during construction activities such as adhesives and paints, and gases such as carbon monoxide, formaldehyde, and nitrogen dioxide, which are products of combustion [21].

iii. Particle (Non-biological) Pollutant Sources

Particles are solid or liquid, non-biological, substances that are light enough to be suspended in the air. Dust, dirt, or other substances may be drawn into the building from outside. Particles can also be produced by activities that occur in buildings such as sanding wood or drywall, microwaving, and operating equipment [21].

\subsection{Common Indoor Air Contaminants in Eateries}

To identify the common indoor air quality (IAQ) contaminants found in Eateries, a number of previous studies regarding IAQ and its adverse effect on health which occurs from poor IAQ are discussed.

Study carried out on Indoor air quality at restaurants with different styles of cooking in metropolitan Hong Kong where four restaurants in metropolitan Hong Kong were selected for the study, the IAQ parameters considered were carbon dioxide $\left(\mathrm{CO}_{2}\right)$, carbon monoxide $(\mathrm{CO})$, particulate matter (PM10, PM2.5), benzene, toluene, methylene chloride and chloroform. The results from their study showed that the mean concentrations of $\mathrm{CO}_{2}$ at restaurants with gas stoves for food cooking in dining areas exceeded the range from 40 to $60 \%$. The average levels of PM10 and PM2.5 at the Korean barbecue style restaurant were high. At the Korean barbecue and Chinese hot pot restaurants, the levels of PM2.5 accounted for $80-93 \%$ of their respective PM10 concentrations [22].

Study carried out on air quality measurements in commercial kitchens were nine (9) kitchens were selected for the study. The IAQ parameters considered were Carbon monoxide (CO), Nitrogen Dioxide $\left(\mathrm{NO}_{2}\right)$, Relative humidity and temperature. The results from their study showed that the levels of contaminants generated in the nine commercial kitchens did not exceed the occupational guideline limits for 8 -hour average. The kitchens surveyed were mainly gas fuelled except for one restaurant that was mostly electric. The lowest nitrogen dioxide level was observed for the mostly electric powered restaurant [23].

Also, [10] Studied investigation of air pollution in restaurants and of employees' personal exposure level at a typical Japanese Yakitori-ya restaurant, (the chicken barbecue restaurant in Japan). The IAQ parameters considered were volatile organic compounds (VOCs), formaldehydes (HCHO) and Nitrogen dioxide $\left(\mathrm{NO}_{2}\right)$. The findings from their study indicated that $\mathrm{HCHO}$ during working periods were in the range from 30 to $60 \mathrm{ppb}$ and $\mathrm{NO}_{2}$ concentration during working period was clearly higher compared with non-working period.

Subsequently, [6] studied evaluation of the indoor air quality in restaurants before and after a smoking ban in Portugal. The IAQ parameters considered were Respirable suspended particulate matter (RSP), total volatile organic compounds (TVOC), benzene (C6H6), carbon monoxide $(\mathrm{CO})$, carbon dioxide $\left(\mathrm{CO}_{2}\right)$, temperature and relative humidity. Ten restaurants were sampled. The findings from their study show a statistically significant decrease in RSP and $\mathrm{CO}$ concentrations after the ban, as well as for TVOC and benzene concentrations. Additionally, the monitored $\mathrm{CO}_{2}$ concentrations widely exceeded $1800 \mathrm{mg} \cdot \mathrm{m}^{-3}$ suggesting inefficient ventilation of the indoor spaces.

[24] Studied Indoor Air Quality of Typical Malaysian Open-air Restaurants. The IAQ parameters considered were particulate matter (PM10), carbon monoxide (CO), temperature and microorganisms (bacteria and fungi). The findings from their study showed that the indoor air quality of the restaurants tested was moderate, only in the 75 th percentile, and the $\mathrm{CO}$ concentrations were slightly elevated indoors. Also, a strong positive correlation between the PM10 concentrations and concentration of airborne microorganisms. Gram-positive cocci (micrococci, streptococci, staphylococci and diplococci) were the dominant microbial morphologies, followed by pathogenic Gram-negative enterobacteriaceae and Gram-positive bacilli.

Study carried out of indoor air quality level in various restaurant in Saudi Arabia where 44 restaurants were selected in two main cities including hotels, family and take away restaurants. At the three locations inside each restaurant, six levels of air pollutants were measured (CO, VOCs, PM2.5, PM10, $\mathrm{CO}_{2}, \mathrm{NO}_{2}$ and $\mathrm{SO}_{2}$ ). The findings showed that the highest mean level \pm standard deviation of PM10, PM2.5, $\mathrm{CO}, \mathrm{CO}_{2}, \mathrm{VOCs}, \mathrm{NO}_{2}$ and $\mathrm{SO}_{2}$ were found in the fast food restaurants, followed by the family restaurants, while the lowest levels were recorded in hotel kitchens and its eating halls [25].

Furthermore, [26] studied Indoor Air Quality in Commercial Kitchens. Indoor air of three different types of commercial kitchens viz., Restaurants, catering centre and Fast-food centre were studied. The IAQ parameters considered were carbon dioxide $\left(\mathrm{CO}_{2}\right)$, carbon monoxide (CO) and particulate matter (PM2.5, PM4 and PM10). The findings from their study show the three cooking environments had $\mathrm{CO}_{2}$ levels above 1000 ppm. For Carbon monoxide it was observed that restaurants, catering centres and fast food centres indicated 7ppm, 8.8ppm and 9.4ppm respectively which are above the permissible exposure levels. In catering centres PM10 levels are found to be the highest. The mean concentration of PM4 in restaurants and fast food centres was within the acceptable limits and in catering 
centres it is found to be high. PM2.5 was found to be highest in the fast food centres.

From the discussion above, the IAQ parameters which are commonly measured are Carbon Dioxide $\left(\mathrm{CO}_{2}\right)$, Carbon monoxide (CO), Particulate Matter (PM), Nitrogen dioxide (NOx), Sulphur dioxide $\left(\mathrm{SO}_{2}\right)$, Total volatile organic compounds (TVOC) Formaldehyde (HCHO), temperature and relative humidity.

\section{Methods and Data Analysis}

This research involved field survey and extensive literature review. Field survey which involved the collection of data on indoor air pollution parameters. The field measurements data was obtained by using Geardon Air Quality Monitor and Tekcoplus Carbon dioxide meter. The population of the study was based on eateries with a specific focus on the functional eateries in Zaria metropolis. There are twenty-five (25) functional eateries within the study area and therefore make the population of the study. Purposive sampling technique was used for the assessment of indoor air pollutants; thirteen eateries were selected based on the design requirement by NAFDAC.

Descriptive statistics and ANOVA statistics was used to compare means and significant levels of the pollutants. The obtained means were merged into one SPSS file for analysis.

\section{Results and Discussion}

Figures 1 to 3 shows the dinning concentration levels of $\mathrm{CO}, \mathrm{CO}_{2}$, TVOC, $\mathrm{HCHO}, \mathrm{PM} 2.5$ and PM10 at thirteen different eateries. The mean level of $\mathrm{CO}(14 \mathrm{ppm}), \mathrm{C} 02$ (710ppm), TVOC $\left(0.203 \mathrm{mg} / \mathrm{m}^{3}\right), \operatorname{HCHO}\left(0.143 \mathrm{mg} / \mathrm{m}^{3}\right)$, PM2.5 $\left(49 \mu \mathrm{g} / \mathrm{m}^{3}\right)$ and PM10 $\left(59 \mu \mathrm{g} / \mathrm{m}^{3}\right)$ were highest inside eateries $\mathrm{F}$ and $\mathrm{M}$. While the lowest were recorded in eateries $\mathrm{B}, \mathrm{C}, \mathrm{E}$ and $\mathrm{K}$. The ANOVA test indicated that there were significant differences $(\mathrm{p}<0.005)$ between the $\mathrm{CO}$ and PM2.5 in the thirteen eateries dining area $(p<0.003, p<0.000)$, while there were no significant differences $(p>0.005)$ for the other pollutants but there was significant increase. These can be attributed to multiple factors that affects their indoor concentrations such as size of indoor area, time of day, season, number of customers, frequent door openings and ventilation system [27-29]. In most of these eateries dining area, there were several appliances distributed in small and narrow area very close to each other. Each of these appliances has its pollutants emission (e.g. $\mathrm{CO}$ and $\mathrm{CO}_{2}$ from ovens) and no doubt the cumulative emissions from these appliances causes high levels of air pollution levels inside these confine areas $[27,25]$. Also, higher number of vising customers in the eateries indirectly caused the higher emission levels. Owing to these factors, the mean level of most pollutants were recorded the highest in eatery $\mathrm{F}$ and $\mathrm{M}$ among others.

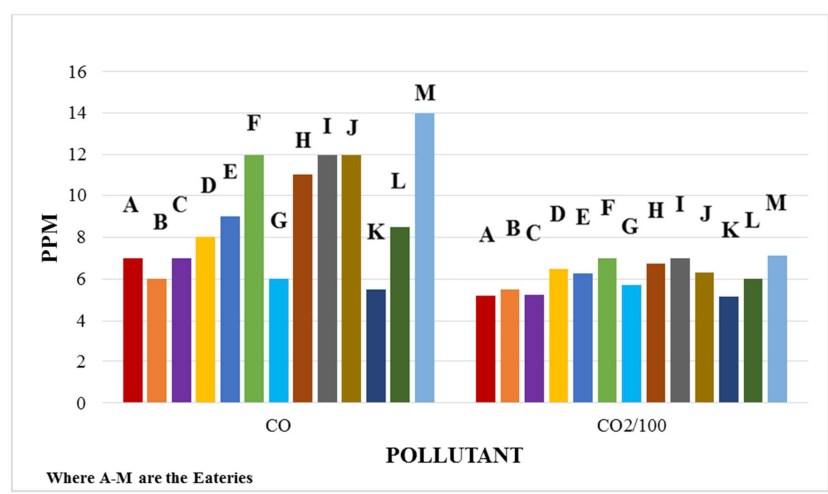

Figure 1. Carbon mono oxide (CO) and Carbon dioxide emitted from Eateries Dinning area.

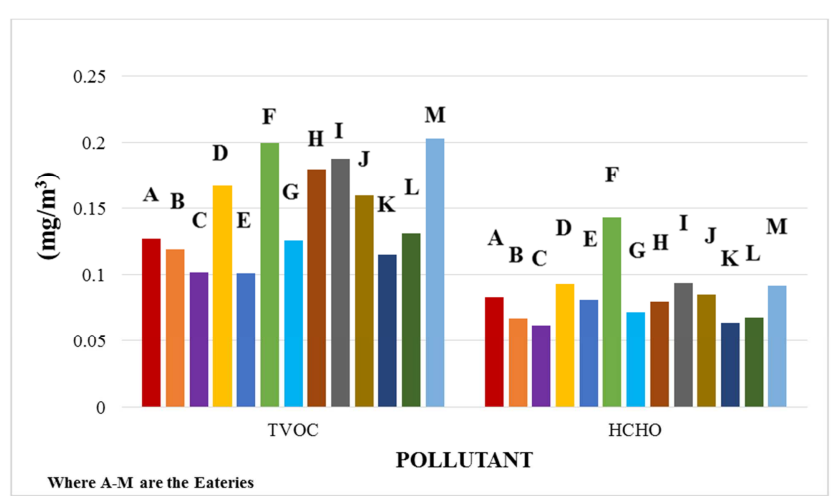

Figure 2. Total volatile organic compounds (TVOC) and Formaldehyde (HCHO) emitted from Eateries Dinning area.

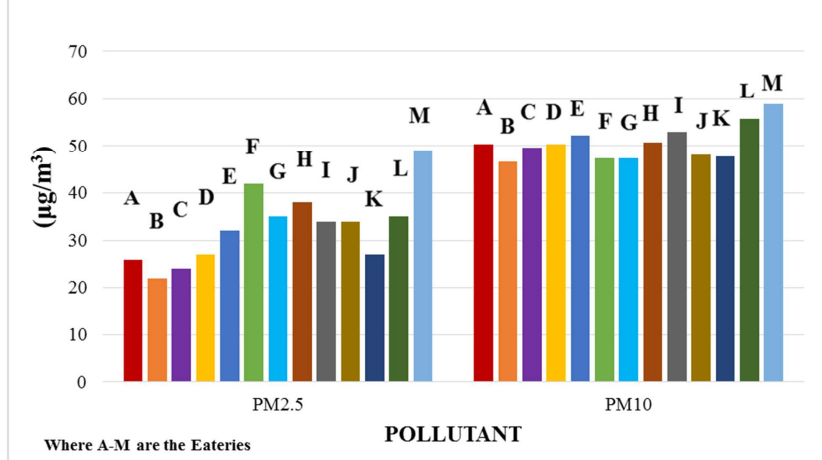

Figure 3. Particulate matter (PM2.5) and Particulate matter (PM10) emitted from Eateries Dinning area.

Figures 4 to 6 shows the kitchen concentration levels of $\mathrm{CO}$, $\mathrm{CO}_{2}$, TVOC, $\mathrm{HCHO}, \mathrm{PM} 2.5$ and PM10 at thirteen different eateries. The mean level of CO (21ppm), C02 (890ppm), TVOC $\left(0.237 \mathrm{mg} / \mathrm{m}^{3}\right), \mathrm{HCHO}\left(0.170 \mathrm{mg} / \mathrm{m}^{3}\right)$, PM $2.5\left(60 \mu \mathrm{g} / \mathrm{m}^{3}\right)$ and PM10 $\left(62.9 \mu \mathrm{g} / \mathrm{m}^{3}\right)$ were highest inside eateries F and M. While the lowest were recorded in eateries B, C, E and $\mathrm{K}$. The ANOVA test indicated that there were significant differences $(p<0.005)$ between the $\mathrm{CO}$ and PM2.5 in the thirteen eateries dining area $(p<0.009, p<0.000)$, while there were no significant differences ( $>0.005$ ) for the other pollutants but there was significant increase. These can be attributed to multiple factors that affects their indoor concentrations such as cooking methods, kitchen size, fuel types, consumption levels, time of day, season, type 
and efficiency of exhaust and ventilation systems [27, 28]. In most of these eateries kitchen area, there are several kitchen and cooking appliances distributed in the areas very close and adjacent to each other. Each one of these appliances has its pollutant emissions (e.g. oil fumes from fryers, $\mathrm{CO}$ and $\mathrm{CO}_{2}$ from oven and grills, and TVOC from meat grills) and no doubt the cumulative emissions from these appliances causes high levels of air pollution levels inside these confine areas [30, 3]. Also, the environmental management procedures where poor inside some of this eateries. These procedures include for example use of appropriate personal protective equipment (e.g. masks and gloves), and inappropriate distributions and lack of appliances, machines, exhaust and ventilation systems. Owing to these factors, the mean level of most pollutants were recorded the highest in eatery $\mathrm{F}$ and $\mathrm{M}$ among others.

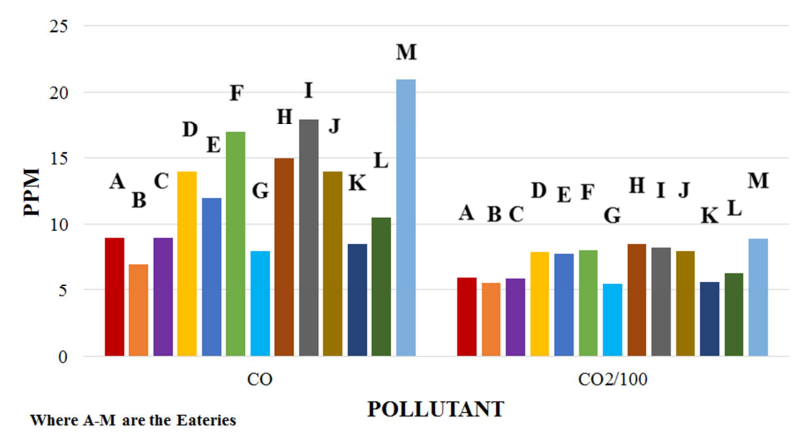

Figure 4. Carbon mono oxide (CO) and Carbon dioxide emitted from Eateries Kitchen area.

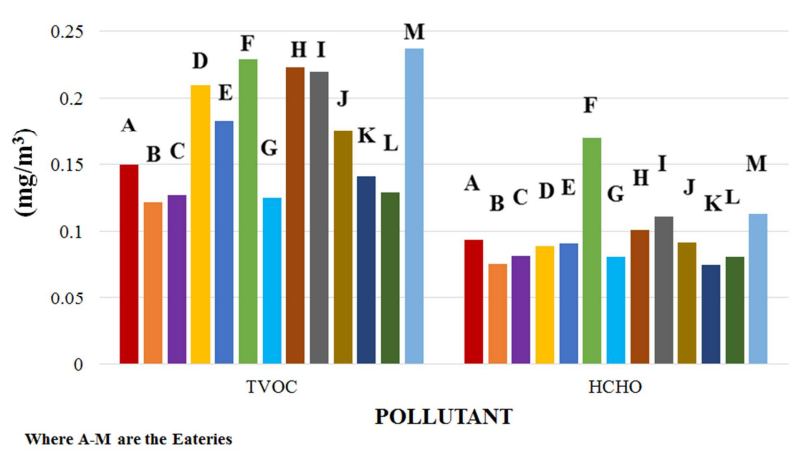

Figure 5. Total volatile organic compounds (TVOC) and Formaldehyde (HCHO) emitted from Eateries Kitchen area.

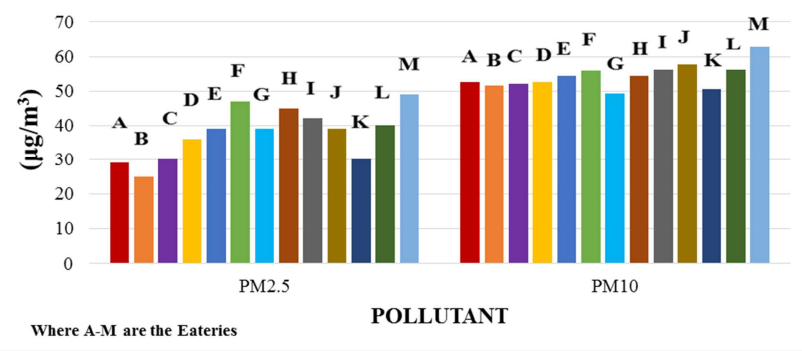

Figure 6. Particulate matter (PM2.5) and Particulate matter (PM10) emitted from Eateries Kitchen area.

\section{Acceptability of the IAQ of the Eateries}

There are few established national or mandatory limits for indoor air quality contaminants, however, there are guidelines. All Mean of $\mathrm{CO}, \mathrm{CO}_{2}$, TVOC, HCHO, PM2.5 and PM10 levels were compared to the ASHRAE Standard 62 which recommends indoor air pollutant concentrations should not exceed the EPA, NAAQS and WHO standard in order to protect public health, etc.

The eatery dinning mean concentration of $\mathrm{CO}$ for eateries (A, B, C, D, E, G, K, and L) were within the ASHRAE acceptable limits of 9ppm. The kitchen of eateries (F, H, I, and M) had a mean CO exceeding ASHRAE acceptable limits of 9ppm. The $\mathrm{CO}_{2}$ mean of all the eateries both Dinning and kitchen where within ASHRAE guidelines of $<1000 \mathrm{ppm}$.

Also, the mean TVOC concentration did not exceed ASHRAE recommended concentrations in the Dinning and Kitchen at all the eateries. ASHRAE recommended a comfort range of $<0.2 \mathrm{mg} / \mathrm{m} 3$ for TVOC while $(0.2-3 \mathrm{mg} / \mathrm{m} 3),(3-25 \mathrm{mg} / \mathrm{m} 3)$ and $(>25 \mathrm{mg} / \mathrm{m} 3)$ is regarded as multifactorial exposure range, discomfort range and toxic range. All the Eateries where within the comfort range. The dinning and kitchen mean of $\mathrm{HCHO}$ of eateries $(\mathrm{E}, \mathrm{G}, \mathrm{I}, \mathrm{J}$ and $\mathrm{L})$ where above the ASHRAE recommendation for HCHO concentration of $0.1 \mathrm{mg} / \mathrm{m}^{3}$.

ASHRAE maximum exposure limit for PM2.5 is $35 \mu \mathrm{g} / \mathrm{m}^{3}$ and PM10 is $150 \mu \mathrm{g} / \mathrm{m}^{3}$ [15]. The mean PM10 concentration of all thirteen eateries sampling location did not exceed the recommended levels. Overall, the mean PM2.5 levels of eateries $\mathrm{F}, \mathrm{H}, \mathrm{I}, \mathrm{J}, \mathrm{L}$ and $\mathrm{M}$ kitchen did exceed the ASHRAE recommendations. This can be attributed to smoke, outdoor air and dust, cleaning (sweeping and vacuuming) and cooking that occurs of which are known to be sources of PM2.5 [32].

The operating temperatures recommended by [31] range from 23 to $28^{\circ} \mathrm{C}(74$ to $82 \mathrm{~F})$ in summer and 20 to $25.5^{\circ} \mathrm{C}(68$ to $78 \mathrm{~F})$ in winter. Indoor relative humidity is recommended to be between 30 and 65 percent [31]. The Dinning mean temperatures of some eateries (A, B, K and L) were within ASHRAE summer guidelines while the kitchen were not within ASHRAE summer guidelines in all Eateries and locations. The mean temperatures exceeded ASHRAE winter guidelines in all Eateries Sampling Locations. The relative humidity for all eateries and locations were within ASHRAE guidelines (30-65\%).

\section{Conclusions}

In this study, we measured the indoor levels of air pollution at different eateries in Zaria metropolis. The results show that $\mathrm{CO}, \mathrm{HCHO}$ and PM2.5 are the most prominent issues causing IAQ problems in the thirteen Eateries within Zaria metropolis also, all the eateries spaces have concentration levels of RH, $\mathrm{CO}_{2}$ and PM10 are within the acceptable concentration range set forth by ASHRAE. The study concluded that there were significance differences $(p<0.05)$ between eateries sampling locations for $\mathrm{CO}(\mathrm{p}<0.003, \mathrm{p}<0.009)$ and PM2.5 $(\mathrm{p}<0.001$, $\mathrm{p}<0.001$ ). Kitchen location had more pollutant concentrations compared to the Dinning location. Cooking areas should have 
an appropriate size and distribution of cooking appliances should be equipped with the proper exhaust, ventilation, and air conditioning facilities and air cleaner. People need to be educated about this problem and increase in public enlightenment on the health and environmental risks associated with this pollutant be frequently embarked upon.

\section{References}

[1] Quarcoo, S., Kwame, J., Ofosu, F., \& Aboh, I. (2012). Particulate Matter and Black Carbon Concentration Levels in Ashaiman. Research Journal of Environmental and Earth Sciences (4), 20-25.

[2] National Health and Medical Research Council, N. (1996). Definition of indoor air. Retrieved February 2018, from www.nhmrc.gov.au.

[3] Gobo, A., Ubong, I., Ede, P., \& Inyang, I. (2009). Indoor and outdoor air quality in selected restaurants and canteens in Port Harcourt Metropolis, Nigeria. African Journal Environmental Pollution Health, 7 (1), 1-6.

[4] WHO. (2016). WHO Guidelines for Indoor Air Quality: Selected Pollutants. Copenhagen: WHO.

[5] Santosh, K. (2010). Ecology and Environmental Studies. Khan Publishers.

[6] Joana, M., Ana. Mendes, \& Helder, S. (2012). Evaluation of the Indoor Air Quality in Restaurants before and After a Smoking Ban in Portugal. Indoor and Built Environment, 323-331.

[7] Zhang, Q., Gangupomu, R., Ramirez, D., \& Zhu, Y. (2010). Measurement of ultrafine particles and other air pollutants emitted by cooking activities. International Journal of Environmental Research and Public Health, 7 (4), 1744-1759.

[8] Zhao, Y., Li, A., Gao, R., Tao, P., \& Shen, J. (2014). Measurement of temperature, relative humidity and concentrations of $\mathrm{CO}, \mathrm{CO}_{2}$ and TVOC during cooking typical Chinese dishes. Energy and Buildings, 69 (7), 544-561.

[9] Juntarawijit, C., \& Juntarawijit, Y. (2017). Cooking smoke and respiratory symptoms of restaurant workers in Thailand. BMC Pulmonary Medicine, 17 (5), 41-51.

[10] Arashidani, K., Nivukoski, U., Inoue, W., Otani, H., Kunugita, N., Kim, H., Uchiyama, I. (2005). Investigation of Air Pollution in Restaurants and of Employees' Personal Exposure Level. Indoor Air, 2718-2722.

[11] Zhang, Y. (2005). Indoor Air Quality Engineering. Boca Raton, Florida: CRC Press.

[12] Norhidayah, A., Chia-Kuang, L., Azhar, M., \& Nurulwahida, S. (2013). Indoor Air Quality and Sick Building Syndrome in Three Selected Buildings. Procedia Engineering, 53 (2010), 93-98.

[13] Kike-Parsis, A. (2018). Indoor air quality. Retrieved from Part 1- What is it.: http://www.medscape.com/viewarticle/494503_4.

[14] ASHRAE. (2007). Ventilation for Acceptable Indoor Air Quality. Atlanta: American Society of Heating, Refrigerating and Air-Conditioning Engineers, Inc.

[15] EPA. (2016). Introduction to Indoor Air Quality. Retrieved
February 2018, from https://www.epa.gov/indoor-air-qualityiaq/introduction-indoor-air-quality.

[16] Pecingina, I.-R., \& Popa, R.-G. (2014). Air Pollutants and the effects of on the human body. Annal of "Constantin Brancusi" University of Tarju-Jui. Engineering series, 213-218.

[17] Indoor Environmental Quality. (2011). Retrieved 5 10, 2018, from http://www. sftool.gov/learn/about/1/indoorenvironmental-quality-ieq.

[18] Stanley, A., Mbamali, I., Zubairu, I., Bustani, S., Andrew, S., \& Joshua, I. (2010). Electric Power Generator Noise Level Characterization and Impact on Selected Commercial Areas of Zaria and Kaduna Nigeria, International Postgraduate Conference on Infrastructure and Environment. The Hong Kong Polytechnic University.

[19] Bake, D. (2013). 7 Common Indoor AIr Pollutants. US Green.

[20] U. S. EPA. (2015). Sources of indoor air pollution-biological pollutants. Washington, DC: US Environmental Protection Agency.

[21] OSHA. (2011). Indoor air quality in commercial and institution buildings. Retrieved from US department of labour, occupational safety and health administration: http:/www.osha.gov.

[22] Shun, C., Li, W.-M., \& Lo, Y. (2001). Indoor air quality at restaurants with different styles of cooking in metropolitan Hong Kong. The Science of the Total Environment, 181-193.

[23] Marks, S. (2002). Air quality measurements in commercial kitchens. United Kingdom: HSE.

[24] Yusri, Y., Mardiana, I., \& Norli, I. (2014). Indoor Air Quality of Typical Malaysian Open-air Restaurants. Environment and Pollution, 3.

[25] Mahmoud, E., \& Wasim, J. (2018). Study of indoor air quality level in various restaurants in Saudi Arabia. Environmental Progress \& Sustainable Energy, 37 (5), 1713-1721. doi: 10.1002/ep.12859.

[26] Shirin, H., \& Mahalakshmi, R. (2016). Indoor Air Quality in Commercial Kitchens. International Journal of Science and Research (IJSR), 5 (10), 1337-1340.

[27] Isler, A., \& Karaosmanoglu, F. (2008, June 16-17). Traditional cooking fuels, ovens, \& stoves in Turkey. Thirtyfirst IAEE International Conference, 20 (4), 54-67.

[28] Kim, K., Pandey, S., Kabir, E., \& Susaya, J. (2011). The modern paradox of unregulated cooking activities and indoor air quality. Journal of Hazardous Materials, 195 (5), 1-10.

[29] Udochukwu, U., Inetianbor, J., Omorotionmwan, F., \& Okpuruka, N. (2016). Effects of High Customer Patronage on the Indoor Air Quality of Restaurants in Lokoja Metropolis and Its Public Health Impact. American Journal of Microbiological Research, 4, 51-55.

[30] Rahman, M., \& Kim, K. (2012). Release of offensive odorants from the combustion of barbecue charcoals. Journal of Hazardous Materials, 10 (3), 233-242.

[31] ASHRAE 55. (2010). Thermal environmental conditions for human occupancy. Atlanta: American Society of Heating, Refrigerating and Air-Conditioning Engineers Inc.

[32] Nazaroff, W. (2004). Indoor particle dynamics. Indoor Air, 14 (7), 175-183. 